University of Louisville

ThinkIR: The University of Louisville's Institutional Repository

Electronic Theses and Dissertations

$5-2011$

\title{
Lessons from the journey : developing and applying an actor's process through embodying "Uncle Peck" in How I learned to drive.
}

K. Obadiah Ewing-Roush

University of Louisville

Follow this and additional works at: https://ir.library.louisville.edu/etd

\section{Recommended Citation}

Ewing-Roush, K. Obadiah, "Lessons from the journey : developing and applying an actor's process through embodying "Uncle Peck" in How I learned to drive." (2011). Electronic Theses and Dissertations. Paper 415.

https://doi.org/10.18297/etd/415

This Master's Thesis is brought to you for free and open access by ThinkIR: The University of Louisville's Institutional Repository. It has been accepted for inclusion in Electronic Theses and Dissertations by an authorized administrator of ThinkIR: The University of Louisville's Institutional Repository. This title appears here courtesy of the author, who has retained all other copyrights. For more information, please contact thinkir@louisville.edu. 


\title{
LESSONS FROM THE JOURNEY:
}

\section{DEVELOPING AND APPLYING AN ACTOR'S PROCESS THROUGH EMBODYING "UNCLE PECK" IN HOW I LEARNED TO DRIVE}

\author{
By \\ K. Obadiah Ewing-Roush \\ B.M.E., Otterbein College, 1985

\begin{abstract}
A Thesis
Submitted to the Faculty of the

College of Arts and Sciences of the University of Louisville in Partial Fulfillment of the Requirements

for the degree of
\end{abstract} \\ Master of Fine Arts \\ Department of Theatre Arts \\ University of Louisville \\ Louisville, Kentucky
}

May 2011 


\section{Copyright 2011 by K. Obadiah Ewing-Roush}

All rights reserved 

Lessons from the Journey:

Developing and Applying an Actor's Process through Embodying "Uncle Peck" in How I Learned to Drive

By

K. Obadiah Ewing-Roush

B.M.E., Otterbein College, 1985

A Thesis Approved on

March 29, 2011

by the following Thesis Committee

Thesis Director




\section{DEDICATION}

This thesis is dedicated to

Sydney, Jordyn, and Langston

who traveled this journey with me

and endured their own tests and trials along the way. 


\section{ACKNOWLEDGMENTS}

I would like to thank Dr. Rinda Frye for always being an uncompromising mentor and wonderfully supportive friend. I would also like to express my gratitude to Professor James Tompkins for choosing to mount our production and trusting me to manifest his vision of the play and my character, to Dr. Nefertiti Burton for making me think in ways I would not have found myself, to Dr. Russell Vandenbroucke for giving me a glimpse of what my father might have been like if he had followed his artistic side, to Ebony Jordan and Amy Cotterill, I could never imagine finding dearer friends.

And last, but not by no means least, I cannot express enough gratitude, respect, admiration, love, and appreciation for my wife, Adrienne, who has taken on all the burdens of work and home because she sees more in me and believes in me more deeply than I may ever comprehend. 


\section{ABSTRACT \\ LESSONS FROM THE JOURNEY: \\ DEVELOPING AND APPLYING AN ACTOR'S PROCESS THROUGH EMBODYING "UNCLE PECK" IN HOW I LEARNED TO DRIVE \\ K. Obadiah Ewing-Roush}

March 29, 2011

This personal narrative briefly describes my past in the performing arts and outlines my training as an actor and my development of an actor's process through various class and performance experiences at the University of Louisville. Through the use of character notes, physical and vocal warm ups, and research into the mindset and vocal patterns of another person I found pathway for exploring, discovering, and embodying the character of Uncle Peck. I further discuss how I can apply this process to other theatre projects and offer my own insights into theatre and why I have chosen this art form as my life's work and vocation. 


\section{TABLE OF CONTENTS}

PAGE

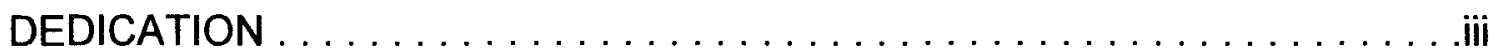

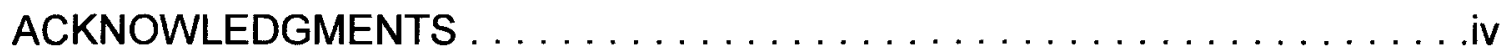

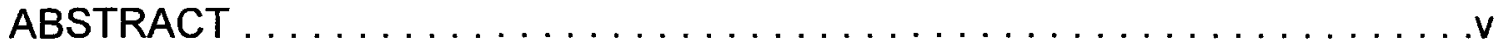

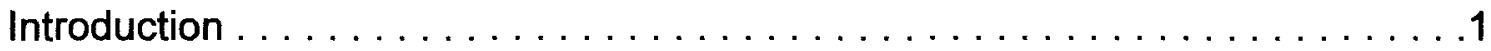

Beginning the Journey: My Past in Art and Theatre $\ldots \ldots \ldots \ldots \ldots \ldots$

The Road Less Travelled: Finding an Actor's Process . . . . . . . . . . . . 10

Classes . . . . . . . . . . . . . . . 10

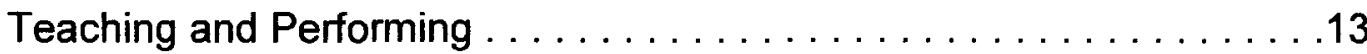

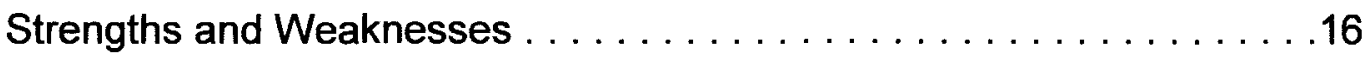

Setting up a Base Camp: Preparing for a Thesis Role $\ldots \ldots \ldots \ldots \ldots \ldots$

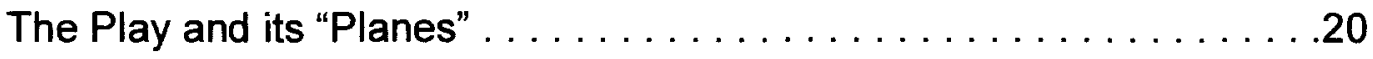

The Thesis Role and its Challenges (Identifying and Addressing Artistic and Actor's Problems) . . . . . . . . . . 24

Research . . . . . . . . . . . . . . . . . . . .

Script-based Research . . . . . . . . . . . . . . 29

Scholarly Research. . . . . . . . . . . . . . . . 29

Body / Voice Research . . . . . . . . . . . . . . . . 31

Physical Research . . . . . . . . . . . . . 31

Dialect Work for Role . . . . . . . . . . . . . . . . 33 
Mapping the Terrain: Application of

My Process in Rehearsal . . . . . . . . . . . . . . . . . . . . . . 38

Journaling . . . . . . . . . . .

Character Notes . . . . . . . . . . . . . . . . . . . . . . . . . .39

Body Preparation / Warm-up . . . . . . . . . . . . . . . . . . 39

Vocal Preparation / Warm-up . . . . . . . . . . . . . . . . 40

Breathing . . . . . . . . . . . . . . . . 41

Reaching the Summit: Applying My

Process to Performance ............................43

More Roads to Take: Using

this Process in the Future . . . . . . . . . . . . . . . . . . . 47

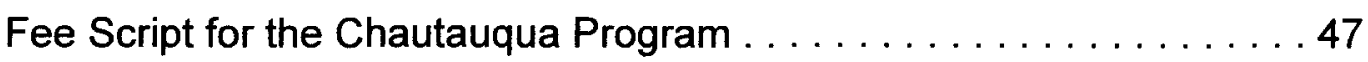

Current Acting Class $\ldots \ldots \ldots \ldots \ldots \ldots \ldots \ldots \ldots \ldots \ldots \ldots$

Why I Continue the Journey: My Ideas about Acting and Theatre Now ....................... 51

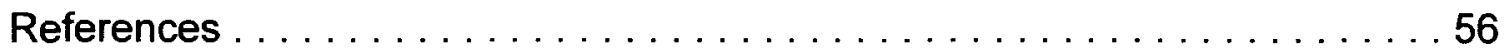

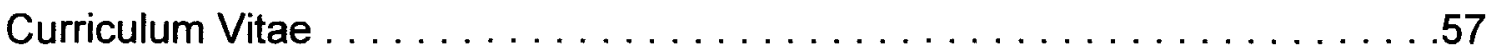




\section{INTRODUCTION}

I regard the theater as the greatest of all art forms, the most immediate way in which a human being can share with another the sense of what it is to be a human being. - Oscar Wilde

Stories are the heart and soul of the actor's craft and work. Whether told in a religious festival, around an open fire, or between two friends, everyone has heard and told stories that guide, exhort, teach, warn, or simply entertain. We all have heroic stories we love to tell about ourselves and humiliating stories we refuse to expose. In an effort to protect ourselves we hide away the hurtful stories, even and especially from our selves. Ironically, the active concealment of these stories is what often causes the most damage and, conversely, can be the greatest conduit to personal healing once we allow those stories to see the light of day. Seeing one's own story portrayed through another can often be the only safe venue for re-experiencing what that story truly means and its ongoing impact.

The story in Paula Vogel's play, How I Learned to Drive, is a heartbreaking, at times grisly tale. Nonetheless, when it comes to sexual abuse, silence is corrosive and shame is detrimental. The play gives voice to a horrific but too often tacit reality. Closeting one's self inside shame and self-blame can, in no way, lead to anything but the perpetuation of a gruesome cycle. Seeing a violation as the victim's fault is a dangerous and horribly skewed view of reality. 
This is why I have dedicated my life's journey to becoming the best theatre artist I can be. I want to better understand and more bravely embrace my own story, I want to find the ways in which sharing aspects of my story, another's, as well as fictional stories can encourage and reinvigorate other people and, perhaps at times, bring a measure of healing to a life that I would have no other way of reaching and helping. Yet, no matter how sincere my intentions are behind helping others, if I do not have the proper tools at my disposal then I cannot do much real good. The training I have received at the University of Louisville and the time spent here has honed my skills, sharpened my instincts, enriched my understanding and appreciation of theatre, expanded my concept of what my theatre work can be, and has taught me to rely on what I know.

The basic building blocks of the actor's work are not just exercises for the classroom or the academic stage. The tools and techniques that have been introduced to me have now become firm fixtures in my own process. Whether rehearsing for the production of a well known classic or creating my own work from the scratch of my imagination, I am now confident in what I know and certain I will never know enough. I have learned that I can open my mind up to new styles and approaches to theatre. This appreciation and acceptance of other theatrical practices grows directly out of knowing for myself what my process is for creating a character and how the end result is often the same: entertaining and healing through storytelling. 


\section{CHAPTER I}

\section{BEGINNING THE JOURNEY: MY PAST EXPERIENCES IN ART \& THEATRE}
Creativity is the urge to wholeness, the urge to individuation or to the becoming of what one truly is. And in that becoming we bring the cosmos into form.
- Jean Houston

I suspect I have always wanted to perform in front of people. I know for a certainty that I have always been terrified of performing in front of people. Despite this trepidation, I have, throughout my life, repeatedly returned to the stage in one way or another. The earliest performance experience I can remember is a Nativity play in my small, country church in Buford, Ohio. I was so nervous the woman who stood behind me had to squeeze my tiny shoulders as a cue for me to speak my one and only line. Sometime later, I impetuously decided to sing a duet with my sister in an evening service. I can still see all the faces of the congregation looking at me and hear my sister every now and then whispering in my ear, "They can't hear you." My voice stayed quiet and small.

Plays in elementary and high school followed but not until high school did I even remotely see theatre as a viable life choice. Part of this evolution in my thought came about because of a live theatre event at my high school. A small nearby college brought a production of Neil Simon's The Odd Couple to our 
rural school. All I remember is the actor playing Oscar, in a rage, throwing an empty coffee can across the stage. The can bounced off one wall of their set and easily rolled up to Felix's feet. The actor playing Felix simply bent over and picked up the can. All the while, Oscar's monologue continued without any stumble and Felix's character stayed apparent and intact. I, to this day, credit this seemingly improvised and uncontrollable incident on stage as the moment I was bitten by the theatre bug.

Despite my affection for theatre I pursued music in my undergraduate training. My first exposure to what trained actors do was during my freshman year as a chorus member with my college's production of Fiddler on the Roof. The director came to each of us in an early rehearsal and gave us a profession. As he sat down near me, he looked down at the floor, thought for a second, then tapped the table in front of me and declared, "Fisherman!" As a musician with minimal high school theatre experience I had no idea how to use this as a foundation for building a character's back story-let alone what it meant to live as a late nineteenth century Jewish fisherman in Russia. Not knowing how to use this information, I quickly rejected his directive. All I knew was to sing my chorus part and move when and to where I was directed.

After college I taught for a short time and then took to the stage again playing with reggae bands for several years. I rediscovered myself in theatre after moving to Nashville, Tennessee. My then fiancé was involved with a grassroots African American theatre troupe called Black Taffeta and Burlap. I started attending play readings which led to helping with productions and 
ultimately appearing on stage. The vast majority of what I knew of theatre and acting before graduate school came from the training I received while with this troupe. The director was Meisner-trained ${ }^{1}$ and gave a brief introduction to the classic repetition exercise. Regrettably, since the director never followed through with this exercise, either by incorporating it into the action of a play or by explaining its significance to an actor, the work seemed esoteric and enigmatic. To a second-rate musician the actor's process remained abstruse and alien.

Theatrically, this director's vision was to tell African Americans' stories with passion and integrity. Her process for coaching actors was primarily oriented towards emotion. "How do you feel about ... ?" was a common question. This became my actor's process; if I could find the appropriate emotional response to any given scene, then I was acting. Despite my limited understanding of and exposure to the actor's process, some of the bravest and most exhilarating work I've done on stage came from working with this group. I had opportunities to portray a variety of personas, from the archetypical slave driver to Harlem Renaissance writer Jean Toomer.

All the while, I was attempting to balance a music career along with looking for professional work as an actor. After several years, neither track developed very far. Frustrated by nearly ten years of auditioning for the few professional theatres in Nashville with little result, I put both theatre and music away and concentrated on raising my two daughters. Eventually, the pull to perform became too strong to ignore. Looking for opportunities in a local paper 1

\footnotetext{
${ }^{1}$ Sanford Meisner (1905-1997) was an acting teacher who worked and trained with the renowned Group Theatre in the 1930s and from there developed his own specific approach and techniques for training actors.
} 
came across an audition for a theatre production which specifically sought a racially mixed cast. I was cast and resumed my journey in theatre.

My acting process during this time was quite haphazard. I would audition for as many plays as I could and take whatever came along-always in community theatre or, at best, semi-professional troupes. I would only occasionally read the play beforehand; usually, my first full reading would be at the first rehearsal. From then it would be a matter of memorizing lines and blocking. My main objectives as an actor would be to find the appropriate emotional response and attitude for any given scene and to be what I thought was the best "director's actor": always on time, memorizing lines promptly, remembering blocking and doing as I was told. In a naïve attempt to show myself as malleable to a director, I made myself bland and neutral in auditions. I realize now this caused me to appear as an actor who was barely able to explore a character on his own and make discoveries in rehearsals.

Similarly, my actor-training before graduate school was piecemeal and quilted together from various teachers, classes, and workshops. One of these classes was led by another Meisner-trained actor, a Rutgers graduate who came to Nashville to start his own theatre troupe. He took the group through the full regimen of the repetition exercise and this benefited me immensely. I found I was truly able to listen to my scene partner and, more importantly, to react to what was being given to me. Unfortunately, this director's approach to training seemed to involve constantly moving the mark towards which the student was striving. In time I was accepted as a member of the company and was able to take classes 
for free and participate in productions but I never felt I was gaining skill and confidence as an actor. Eventually, I had to stop taking classes because of work conflicts and family commitments. Despite having trained with this company and continuing to audition for them, I was never again cast in one of their productions.

For better or worse, this emotion-centered process became my process for years afterwards. The worst consequence of this approach manifested for me in a community theatre production of Tracey Scott Wilson's The Story. I was playing the character Jeff who is a newspaper editor. The paper has recently hired his lover, Yvonne, and he is trying to keep their relationship secret. As the play progresses it becomes apparent that Yvonne has fabricated a source for a news story which she hopes will further her career. Early in the run of our production I found a truly moving and unexpected emotional reaction during Jeff's final confrontation with Yvonne. It was, I felt, the emotional life of the scene and I thrilled at the visceral experience. My acting process told me to reproduce this emotional state at every subsequent show. Even while I was experiencing myself as artificial and self-consciously producing an emotion I continued to produce this emotional response purposefully, knowing no other way of being in character.

Along with this psycho-emotional process I developed something of a physical process as well. Although this physical routine would change somewhat for each show, it was basically the same, and involved stretching, jogging, and singing to get my voice ready to fill whatever house I was in. I learned to listen for the reverberation of my voice in the hall and tried to project when I did not hear it. 
I was heard by, at least most of the audience but at the expense of vocal tone and color. Later when watching at a video of one of my performances given before my graduate training, I realized how nasal and even strident my voice was.

Despite the limitations of my physical and psychological processes I was able to reach two significant milestones. First was performing as Matt in a community theatre production of Lanford Wilson's Talley's Folley. I auditioned for this play with no intentions of doing the play and absolutely no knowledge of the play itself; I simply wanted the producers to remember me when I would audition for another play later in their season. When offered the part, I accepted with, again, no knowledge of the play. After the first read through I was flabbergasted at what I had gotten myself into. The play has only two characters, is ninety minutes long with no intermission, and my character carries the lion's share of the lines. I would have never auditioned for this play or accepted the role if I had known what I was in for; I truly didn't believe I had the talent or ability to carry the role. However, I knew the director personally and was not going to back out on him. On top of this I was cast with a professional working actress. So, I ramped up my pre-show routine, worked hard on learning lines and became completely dependent on my director while still trying to remain alive and available to my fellow cast member. Ultimately, this production solidified for me the idea that I could be an actor and could carry a substantial role while doing more than an adequate job in the process. 
My second benchmark came in my first professional show. I auditioned for the inaugural season of the International Mystery Writers' Festival held in Owensboro, Kentucky. Despite being a completely unknown actor to the local and Chicago-based directors of the six different plays being produced for the festival, I was cast. I drove the hour-long trek between there and my home while still working my day job. I was able to keep up with the other professional actors and even developed a rapport with them. Ultimately, though, I felt myself falling back into recreating emotional responses and regurgitating previous reactions. Nevertheless, these milestones affirmed for me that the stage is where I belong and I feel most like myself when working to give a quality performance. I became determined to go to graduate school to hone the skills I knew were lacking. 


\section{CHAPTER II \\ THE ROAD LESS TRAVELLED: FINDING AN ACTOR'S PROCESS}

Who are we and what are we doing here?

-Susan-Lori Parks

\section{Classes}

In graduate school I was immediately introduced to the concept that goals and intentions are the heart of the actor's off-stage work and the character's onstage life. Finding goals that are compelling and appropriate for the character and the scene seemed to take a long time solidifying into a regular habit. I was still conditioned to my emotionally oriented process and felt I should always feel something first; if not, then I needed to generate an emotion. Additionally, I was inhibited by feelings of inadequacy because of my lack of experience and always worrying about "looking foolish" or doing things "wrong" and not forgiving myself for simple transgressions. I had an all-or-nothing attitude; if I did a scene well I was a good actor; anything less than perfect was all wrong. While at the university I have had to learn to let go of this perfectionism in my acting, my academic efforts, and other areas new to me such as playwriting. In acting particularly, I was, again, looking for the "right" way to perform a role or scene, and felt that once I had that I was "acting." 
My first graduate acting class was a harsh wake up call, a process of scraping away the calluses and scabs of my inept process and misguided assumptions about acting. I felt I neither found the essence of acting nor saw myself as an actor during this first class. I often felt despondent and dismayed at my inability to "get it" and do better. Seeing work done by third year students, particularly Sarah Carleton, and hearing encouragement from Jerry Rose that he had his own set of issues to overcome kept me persevering though still often falling short through this difficult time.

During these early months I did not develop a well-grounded understanding of goals and intentions and how those serve the actor on stage. I was instinctively touching on this from time to time but no real conscious effort was made since I had no conscious awareness of the process of finding and pursuing compelling goals. I would have "sparks of brilliance" as Rinda Frye, my Hamlet director, observed in one of my student evaluations, but I could not yet let go of these moments and trust that new inspirations would come. In these moments I feared I had found the apex of the emotional content of the scenes and anything different would be inferior and, thus, would expose my fraud of pretending I am to be an actor and an artist. Nonetheless, I performed my first Shakespeare role in my first semester and closed the show feeling I had done, at least, an adequate job.

The Audition Workshop class my second semester was a great shot in the arm. Monologues have long been difficult for me to perform well and I often thought of this shortcoming as one reason for never being hired by professional 
theatres while in Nashville. I began the class still trying to produce emotional results. The instructor's constant guidance of "pare it down and keep it simple" finally worked its way into my subconscious. Though I never felt I had achieved what I thought my professor wanted, she commented that I was her greatest surprise of the semester and that I had found the essence of the monologues through a simple, unproduced delivery.

Voice classes through my first year were in and of themselves invaluable in helping me begin the heart of my journey of self-discovery as an artist. I was beginning this sojourn in graduate school with too much personal baggage for a free and spontaneous actor. Voice classes brought me in touch with my own unique, natural physical instrument as well as the things-physical and psychological — that prevented me from fully expressing myself on stage or, more importantly, from accepting that I do have something valuable and legitimate to give as an actor and an artist.

I was fortunate to have an opportunity to apply the training from my first year right away. I was cast in a production that began rehearsing immediately after the school year ended. The cast was only three actors and the script was new so the director made room for everyone to contribute to the storytelling and staging of the play. At that point all that I could remember about what I had learned in my first acting class came to bear, namely: find what helps to tell the story, get rid of what does not, and find how to justify any particular line or action. Instead of spending an entire summer working to make money while forgetting skills and lessons from the previous nine months, I immediately applied these 
skills and lessons directly to my craft without worrying about being graded or fretting over the approval of a professor. I made every effort to create art that had integrity and was solid aesthetically. This freedom enabled me to relax and allow the benefits of pre-show warm-ups and the discoveries made in rehearsals to settle into my body. I could sense myself becoming more at ease with what I was trying to do on stage and to bring out in my characters. Even though I still had many pre-graduate training habits, I felt that this performance was one of my most relaxed and responsive stage efforts to that point.

\section{Teaching and Performing}

Perhaps the greatest benefit in my development of a process came in my second year, specifically the second semester of that year. This benefit was actually two-fold. I began teaching my first Acting for Non-majors class and, at the same time, was cast in Moises Kaufman and the Tectonic Theatre Project's The Laramie Project (the story of the aftermath of Mathew Shepard's brutal murder in Laramie, Wyoming). I lacked confidence as an acting teacher. I had felt secure as a section lecturer the previous year, reinforcing another professor's curriculum and leading group discussions. But when it came to teaching what it truly meant to act I felt I barely knew what that was and would again perpetuate my fraud of being an actor and artist. I knew nothing about finding beats and scoring a scene, yet had to teach and grade these things in class. I hoped the students would find the class fun and look forward to it but, at the same time, not have it be so easy that the subject could simply be dismissed and the class not taken seriously. I wanted my students to gain a real understanding of what acting 
truly is and become better able to appreciate and, more to the point, evaluate what they see. Still, I walked on eggshells with my students trying to find the line between too lenient and too harsh.

With The Laramie Project I was able to take on a number of roles, differentiate them, and find compelling goals to pursue even though most of the time I was performing monologues. The first thing I did was to take notes on each of my characters during the table readings, beginning with the character descriptions in the script. Then, as other characters made comments about any one of my characters I noted that as well; this was a rarity, though, since the majority of the script is in the form of monologues from interviews. I also made notes of different vocal placements (where in the mouth the vocal sound is aimed) I would use for each character. This process of taking character notes from the start of rehearsal was spontaneous and new for me. I would make notes here and there through rehearsals of previous shows but never like this. I found this to be an invaluable tool for exploring and developing my characters. It kept me from making all the characters similar and helped me to find not only goals for individual scenes but a super-objective (or "world view") for each character.

The most salient example of this was with Matt Mickelson, owner of the Fireside Bar. At first, I simply thought of him as promoting his own business, then later trying to save his business. I finally realized he was trying to save his own reputation. In her book, The Meaning of Matthew, Judy Shepard, Mathew's mother, says Mickelson wanted the community to see the Fireside as a place where anyone and everyone could come. I imagined the shock that his sanctuary 
of tolerance would be used as a staging ground for a vicious and bigoted crime. "Perhaps the Fireside won't survive," I surmised as this character, "but if my reputation as a tolerant and accepting person is tarnished by this act I have no future in Laramie. My family has been here for over one hundred and fifty years. I cannot let this happen to me and my family's legacy!" I discovered that this outlook and super-objective informed and fueled everything Matt Mickelson said and did throughout the play, from initially talking with the Tectonic Theater Project members to his statement about wanting McKinney and Henderson to stay in jail for the rest of their lives "and never come into [his] bar again."

While I was perhaps too harsh on myself as an acting teacher, being in charge of an acting class while working hard to find my footing amongst so many characters fed my creativity and compelled me to hone in on specific and succinct goals and intentions so I would not look empty, foolish, and fraudulent in front of my students if they asked very particular questions about my work and characters. (Ironically, they never did.) This was the dichotomy of my strengths and weaknesses as an actor. I did not yet fully trust my instincts or my artistic ability; hence, I was too harsh on myself and viewed my shortcomings as proof that I was a fraud. Because of these perceived shortcomings I worked very hard at thinking through and justifying what I did on stage and, consequently, achieved a solid performance. Moreover, most of my development and training in graduate school has been hindered by my tendency towards chronic self-consciousness. My near constant self-criticism and second guessing filled me with fear and worry that I would, yet again, "look foolish" and prove my ineptitude as a theatre artist. 
Tenacity in honing my skills as an actor and the occasional external validation of my efforts has been an immense boost to my self-assurance as an artist.

In that vein, I had the opportunity to teach another Acting for Non-majors class in the summer before my third year of graduate school. This session made it obvious to me that I do know what works and what is effective in a theatrical performance. While I was very aware that I did not know as much as my professors (and battled the feeling that my students would be better off learning from them) I acknowledged to myself that I had-and have-something of value to impart to those who are under my guidance.

In addition to this teaching experience I auditioned for the Kentucky Humanities Council's Chautauqua program. This program hires actors to portray significant people from Kentucky's history by presenting one-person shows throughout the commonwealth. I decided on John Gregg Fee, abolitionist and cofounder of Berea College and used his autobiography as the basis of my writing and portrayal. This was more nerve-wracking than I had expected. I was not only auditioning as an actor but also presenting material that I had written out of my own creativity. Being accepted into this program confirmed for me that I can create compelling theatre and commit with conviction to the emotional life of a character I am creating.

\section{Strengths and Weaknesses}

My process going into my final year of graduate school was much stronger and active than even during the Spring Term of my second year in this program. Although I was still somewhat inhibited by my lack of self-confidence, I gained a 
great deal of trust in my acting abilities and, finally, fully embraced my personal identity as an artist. Not long before this I was quite reticent to warming myself up physically or vocally around others. With diligence and focused work, I came to rely on thorough warm-ups to open up my creativity and responsiveness in rehearsals. Since Professor Tompkins, director of my thesis play, does not employ group warm-ups as part of rehearsals, I began to take myself through a thorough warm-up regimen and invited anyone in the cast who wished to join me.

While the pressure of delivering a quality thesis role performance fired my focus and concentration, I tried to stay vigilant against another stumbling block in my work: my stubborn will. While this can and has served me well through graduate school it has also proved to be a serious detriment to fresh and creative exploration of character and storytelling. To work against this, I tried to concentrate only on memorizing lines without preplanning how to deliver a line or emotional states.

I was all too aware, as well, that another weakness in my work is a lack of self-awareness. I have often thought that I was doing more physically or vocally on stage than I was. This became painfully obvious during dialect work in my Voice IV class spring term of my second year. After performing a monologue in class with what I thought was a dead on British accent, I was told by the instructor that I had a good "hidden dialect" (a neutral way of speaking so one's regionalisms are not apparent). This was nothing short of devastating. In that moment I was living my worst nightmare: performing in front of others at a level drastically lower than where I believed I was. After the tears and anger subsided I 
was able to re-approach that particular dialect. I never got a firm grasp on the British accent in that class but I did learn to not give up and to rely much more on the feeling inside my mouth for how a dialect is formed and produced instead of relying solely on my ear. Before, I had always used my ear as the only guide to the accuracy of an accent and I had to admit that this was unreliable. Instead, learning to feel the shape of the tongue and the placement of the voice in the mouth became vital to performing Peck's South Carolina accent without sounding forced or undermining the sympathy for him I hoped to spark in the audience.

By the time the role of Uncle Peck was definitely in my near future, I had a fairly well grounded understanding of my abilities and limitations as an actor. I knew I could memorize through consistent and diligent work and that I needed to always to search for how to justify my character's actions. I knew how to find compelling goals and had grown tremendously in understanding and using my vocal mechanism. Alongside these and other strengths I still had to struggle against my weaknesses and stubbornly persistent bad habits. I still was rather unsure of myself as an artist at the beginning of the semester. I still often allowed the end of my lines habitually to fall downward in pitch and very often did not hear it for myself. This downward inflection at the end of a sentence is often used in everyday conversation to indicate a thought is finished or that another person can take a turn to speak. While this may enable an actual conversation to progress, this downward inflection is deadly in a theatre performance. The effect is that the energy shared and reciprocated between two actors or an actor and 
an audience becomes diminished and the characters come across as not at all invested in their own goals and desires

Perhaps the greatest stumbling block that remained in my work was allowing myself to become overwhelmed by simply not knowing what I was doing as a character and or what would happen next (and if I could handle it). Once this feeling of being overpowered set in, I would not make any kind of real acting choices. Instead, my voice would get sonorous and produced, a sure sign I am not connected to my character's intentions. Having worked with Professor Tompkins in the theatre department's Repertory Company, I knew the cast would have a great deal of room to contribute to the blocking and storytelling. This pushed me to reach beyond my comfort zone of inaction and my constant search for external approval to become open to and led by my impulses. If an idea did not work, that did not mean all my creativity was gone. As I started to study the script over the summer, I made some initial choices for goals and tactics and characterizations for Peck. The more I read, worked on, and learned about the play, the more excited I grew to take on this challenge. 


\section{CHAPTER III}

\section{SETTING UP A BASE CAMP: \\ PREPARING FOR A THESIS ROLE}

Imagination is more important than knowledge.

-Albert Einstein

\section{The Play and Its "Planes"}

In his book, Creating a Role, Constantin Stanislavski ${ }^{2}$ discusses the various "planes" in which a play exists and its roles live. He labels and defines these as follows ${ }^{3}$ :

1- the external plane: "facts, events, plot, and form,"

2- the literary plane: "the play's ideas, style, and other aspects,"

3- the plane of social situation: "class, nationality, historical setting,"

4- the aesthetic plane: "all that is theatrical, artistic, having to do with the play's scenery and production,"

5- the physical plane: "fundamental laws of physical nature, physical objectives and actions,"

6- the psychological plane: "inner action, feelings, inner characterization," and

7- the plane of personal creative feelings "belonging to the actor." (p. 12)

${ }^{2}$ Stanislavski (1863-1938) founded the Moscow Art Theatre in 1897 and in time revolutionized how actors approach their craft and created what has been the basis for much of Western theatre training for generations.

${ }^{3}$ I have reordered Stanislavski's original list for the purposes of this thesis. 
Stanislavski goes on the say that these planes are not of equal significance and that not all of them are easily discernable. Nevertheless, I will, in this section, discuss the play's plot and the 2010 production at the University of Louisville through this framework focusing on the first five planes.

How I Learned to Drive premiered on Broadway in mid-March 1997. Its author, Paula Vogel, received the Pulitzer Prize for the play the next year and is currently Chair of the Playwriting Department of Yale University. It is the story of a woman called Li'l Bit and how she survives the emotional neglect and abuse of her family and the sexual abuse and manipulation of her Uncle Peck. I first heard of this play while still in Nashville. I did not see the local production or read a script but I was fascinated with a newspaper review's description of the opening scene between Li'l Bit and Peck. Years later in graduate school, the play was part of the reading for the Enjoyment of Theatre class for which I was a teaching assistant. Upon reading Vogel's theatrical portrayal of an out of body experience, I knew I wanted to play Uncle Peck one day. As fate would have it, I pitched the play as a possible thesis role the next year and rest is history, recent as it is.

On the external plane, the play reveals Li'l Bit's story through a nonsequential series of remembrances as Li'l Bit leads the audience through her experiences at home, in school, and, most importantly, with her Uncle Peck. Li'l Bit introduces the play to the audience enigmatically saying "Sometimes to tell a secret, you first have to teach a lesson" (Vogel, p. 9). From there the audience is introduced to the nature of her relationship with her Uncle Peck as he and Li'l Bit share a summer evening in the front seat of his car. The audience learns that 
these clandestine meetings are a regular occurrence and that Peck resists drinking more to impress his niece than for his own good. Then, Li' Bit's familyher mother, Aunt Mary (Pecks' wife), and her grandfather-is seen at "a typical family dinner." The audience sees from the start of this scene how little social and emotional support Li'l Bit receives from her family. Her grandfather, Big Papa, comments right away about the size of her bust line. Throughout this scene it is painfully apparent that he sees Li'l Bit as nothing more than a future wife and breeder. This is, also, the first hint at the real dichotomy and complexity of Peck's relationship with Li'l Bit's blood relatives. All through the conversation, Peck walks a thin line of supporting Li'l Bit while not crossing Big Papa. Even after Li'l Bit storms out and Peck sincerely comforts and advises his niece about the importance of family, he refuses to allow Li'l Bit to use his car to get away and be alone without a coerced agreement to meet him later for one of their trysts.

These opening scenes establish much of the play's literary plane along with its plane of social situation. The latter is clearly delineated right away in Li'l Bit's opening monologue and in the car scene where Peck seems to not know about Herbal Essence shampoo (a new product at that time). The family dinner shows the lower social class from which the family hails and above which Li'l Bit is desperately trying to rise. On the literary plane, the presentational style of the play is immediately apparent. This play is not written in a more familiar representational style where the actors never acknowledge that an audience is present. Li'l Bit directly addresses the audience as do the actors who portray the 
family as well as others in Li'l Bit's life. These auxiliary actors speak short transitional lines that help to keep clear for the audience the back and forth route through time that the subsequent scenes take. Though the full theme behind the play-surviving abuse and finding the capacity to forgive-does not become apparent until the end of the final scene, other ideas of the play are also introduced during this time; namely, that this is Li'l bit's story told from her perspective and that Peck is the second most important person in her life. This becomes apparent through the aesthetic plane.

Of the various characters, only Li'l Bit and Peck are played by the same actor. The other three actors take on all the other characters as well as portraying "neutral" personas, so to speak, giving the transitional lines and announcing the scenes' titles. The University's production took this concept of protean actors a step further. The two women and one man, called the Greek Chorus, not only portrayed family, friends, and strangers in Li'l Bit's life but objects as well. This was especially symbolic as the trio formed the front of the car where Li'l Bit and Peck meet. The Chorus of the ancient Greek tragedies, originally representing the citizenry, was an omnipresent group of judges of the actions of the nobility, the plays' main characters. Similarly the Greek Chorus (representing Li'l Bit's family) in the university's production was always a presence for Peck and Li'l Bit, if not physically then in the back of their minds as their illicit affair grew more and more torrid and dangerous. Furthermore, the stage set was quite bare; a table and five chairs were the only consistent pieces. 
These items became a dining room, a restaurant, and the car Li'l Bit and Peck often shared, just to name a few.

This made the physical plane of the production especially important since the use of costuming and props was also quite minimal. Small costume pieces were added to the Greek Chorus' all black base costumes to portray the various characters and mime was use extensively as well. Despite the play's non-realistic form, the physical reality of the individual scenes had to be as accurate as possible. The size of the steering wheel and roominess of the interior of a 1956 Chevrolet, the shock of the initial blast of a hot shower, and the simple but detailed act of fishing had to be clear in the actors' minds and bodies in order for it all to be real in the audience's minds. This clarity in the on-stage physical actions kept the route through the play's emotional landscape clear and navigable for the audience. The remaining two planes, the psychological plane and the plane of personal creative feelings, will be addressed in the following section, though not by name.

The Thesis Role and its Challenges (Identifying and Addressing Artistic Problems and Actor's Problems)

Making Peck truly sympathetic and not pathetic or merely monstrous was a great challenge and my main actor's goal. While initially he presents simply as a pedophile and child molester, he is truly in love with Li'l Bit. Despite being married to her aunt, Peck is emotionally dependent on Li'l Bit and needs to have the time with her that they regularly set aside. Another challenge was the major 
monologue Peck has in the middle of the play. As I stated earlier, monologues have been difficult for me and this one is substantial.

While Peck has designs on Li'l Bit from early in her childhood, the quality of his relationship and desire cannot be the same throughout the play. The various and distinct stages in the evolution of his desire and intentions toward Li' Bit during the different times of his life had to be displayed clearly. This was particularly challenging since that play's events are presented out of chronological sequence. To address this, I made for myself a timeline of the play's scenes.

This chronology was revealing. The first scene of the play takes place only six months before Peck will ask Li'l Bit to marry him. But, in the context of the order of the play's scenes, these two events seem distant from each other. The act that starts Li'l Bit down the road of enmeshment with Peck, his first molestation of her, is one of the very last scenes. Reviewing the play's scenes chronologically led me to realize that the play mirrors a series of therapy sessions. The initially revealed incident does not seem that serious in and of itself. Yet, as one digs deeper, more and more hurt and betrayal come to light. The ultimate violation of trust and personal damage is revealed last, much as a client in a therapist's office does not jump immediately to the deepest, most painful trauma.

Another great test for me was to portray Peck's military experience, which is still engrained in his body and outlook to a certain degree, since I have had no military exposure at all. Even though my father served in World War II, he went 
only because he was drafted and seemed to have put the experience away when he got home. The discipline he exerted in our home was more that of a stern father than a militaristic martinet. Peck is not a father so I knew to avoid being fatherly and, instead, portray a man who is accustomed to things happening at the bark of an order. Interestingly, this militaristic demeanor did not come through in his interactions with Li'l Bit as much as I had expected. One major scene where this attitude was manifest was in the actual driving lesson. Peck loves cars and respects their power. He clearly displays his true concern for Li'l Bit all through this scene. Peck tells her "I will never touch you when you're driving a car," and "I'm going to teach you to think what the other guy is going to do before he does it" (Vogel, p. 34-35). He demands full attention and seriousness from Li'l Bit during this scene. Even as Peck equates the power of driving with the thrill of sex, he does not allow these driving lessons to degrade into another illicit encounter between the two.

While sexual activity is not a prominent part of the play's action, it is an integral aspect of the story. Presenting my own sexuality was a frightening challenge. I do not see myself as a prude, but showing how I appear and behave during a sexual act was intimidating. In Movement class I came to the difficult realization that I have been more than somewhat detached from my body. Although I am now much more aware of how I move, where I hold tension or even what that tension feels like, I certainly have never analyzed how I move and contort during sex or even what I do during a seduction. In the latter part of the play Peck does sexually climax against Li'l Bit during their first drive together. At 
first this scene was to be done with the actress playing Li'l Bit sitting on my lap. When the suggestion was made that Li'l Bit stand downstage and watch the "memory" of this first violation, we were less than a week from opening. I immediately became quite nervous and frightened. I told the director that I knew it would be an effective scene because of the fear that flared up inside me.

Despite the difficulty of performing this act "in the moment" while losing my selfconsciousness, I believe it had quite an impact on the audience

I knew as well that another great challenge to portraying Peck effectively would be my insidious habit of a vocal downward inflection at the end of lines. Even in my third year of study and training I still did this, even as I thought I had pitched the end of a sentence upward. As Professor Tompkins quoted Pakistani actor Zia Mohyeddin, "The bane of every actor is the downward inflection." I am striving to rid myself of this habit by becoming more aware of its occurrence in my everyday speech and on stage, and to freely experiment with different inflections to help me find my intention behind every line.

Even though this is still becoming a regular habit for me, the importance of an actor's vocal awareness was driven home for me early in my graduate training during rehearsals for Abe Lincoln and Uncle Tom in the White House, an original play commissioned by the theatre department's African American Theatre Program. This play revolves around a fictional conversation between the two men for whom the play is named. The director, Dr. Lundeana Thomas, called for "vocal variety" throughout the rehearsal process. Being forced to push my voice into new ranges and registers, while not yet familiar with lines and 
intentions, made room in my voice for those ranges and registers. Despite feeling that I was going into these vocal areas self-consciously and only because I was directed to, I could feel the difference as I found more and more tones and notes in my speech. I could hear in the rehearsal room, as well as the performance hall, how much more ability my voice had. My voice teacher commented that she had not heard such a range and variety come out of my voice before that performance.

It was vital for me to keep all of this in mind since How I Learned to Drive would be presented in a very bare style with minimal props, set dressing, and costumes. The relationships and circumstances of individual scenes would come across clearly only if the acting was sharp and focused. This was a thrilling prospect for me. No theatrical "tricks" (light changes, music underscores, etc.) would assist me in portraying any given event or intention. It was vital that I was certain, clear, and confident in the pursuit of my goal with the other characters, particularly so with Peck's major scene, the "fishing" monologue. The play utilizes three protean actors-called a Greek Chorus-to portray various characters throughout Li'l Bit's story. Even with all three of the Greek Chorus acting as fish in the water, there was nothing onstage to help me get across the story in this monologue. I felt strongly that it should be that way. At one point the director was toying with the idea that the male member of the Greek Chorus would portray the little boy that Peck seduces. I advised against it. The audience could not be allowed to distract themselves visually or mentally from the sheer discomfort and disgust that this moment could conjure. I knew I had to invest fearlessly-on 
psychological and physical levels-in what Peck is attempting to do to this little boy but I also had to portray his intentions realistically so that the man would be seen as a human being, even if broken and misguided. Obviously, in order to achieve a portrayal of things outside my own life-experience research was vital.

\section{Research}

\section{Script-Based Research}

Reading a script is, perhaps, the first bit of research that an actor undertakes. Knowing how my character fits into the overall story and dramatic structure of the play is the lens through which I read a play for the first time after being cast. Before graduate school, a first reading for me was more about what my role was in the play and how often I was on stage and what challenges my lines would present. Being required to read so many different plays for the academic classes of the program I have learned the value of looking at the first time reading a play as a chance to see the entire play on an even keel. I wish to note that since I came across the previously discussed planes only in the writing of this thesis, they were not a part of my research. However, this will be a facet of script research from now on.

\section{Scholarly Research}

My research outside of the script consisted mostly of trying to understand the mindset of a man who is not only attracted to children but also perpetrates this behavior within his own family. Pamela Schutlz's book Not Monsters provided tremendous insights into not only the mind of a perpetrator but those who are victimized, as well. Schultz is very open about her own history of abuse 
but her work with perpetrators has been geared specifically to understanding the damage that had been done to them as children. This perspective of a victim seeing her perpetrator as a victim was stunning to me. Schultz even says of her abuser, a next door neighbor well loved and respected in the neighborhood, "[after his death] I had to admit I still loved him but not in a sexual way, but as a father figure or perhaps a valued friend, who must have been terribly wounded himself to have hurt me so badly" (xiii). This shows an astounding measure of forgiveness and compassion and it focused much of my character work for Peck on what his past must have been in order to justify for myself, as an actor, his continuing to commit such violations.

Nonetheless, as unfathomable as this sympathy and understanding were to me, a later statement was a true revelation. Shultz goes on to say "I had to accept that the wrenching realization that everything inside me existed because of-or in spite of-my childhood victimization" (xiv). This made clear that I would need to find the things inside Li'l Bit that Peck gives her through his grooming and abuse and I would have to play those moments for what they are. The most obvious manifestation of this is in the driving lesson scene, but also in the photo shoot scene where Peck is encouraging and nurturing Li'l Bit's sexuality that, in turn, becomes expressed in Li'l Bit's description of, as a grown woman, her seduction of a high school student and which led to finding a deeper level of understanding her Uncle Peck.

In addition to Schultz's invaluable work, my wife is a social worker and has worked in many different areas of the field. At the time of this production she was 
working with juvenile sex offenders. This was an area new to her so she had articles and recent training concerning this and was eager to help me understand the mental process of a sexual perpetrator. This revealed to me one significant and extremely useful reality of perpetrators: they very often have some sort of "trigger"-a stimulus which sparks the brain's neurons to fire in a familiar pattern.

Tragically, this pattern manifests in the justifications and denials necessary to allow someone to so horribly violate another person. At one point in rehearsals Professor Tompkins directed me to rub my hand across cousin BB's head during the "fishing" monologue. I soon realized that this could be the physical trigger to Peck's more intense sexual advances. Although I only used this two or three times, it was a wonderfully real and concrete action that viscerally connected me, as the actor, directly to my character's goals and tactics. Moreover, that action served as a reverse trigger for me in the hotel scene. When Peck has finally lost everything-Li'l Bit, his wife, and his own selfrespect and dignity—and had crumpled onto the floor, Lil Bit compassionately reaches out and rubs the back of Peck's head. I had imagined for myself that Peck's own violation as a child involved this same action. Feeling the actress' hand touch my hair seemed to never lose its punch for me during our short run.

\section{Body I Voice Research}

\section{Physical Research.}

One particular weakness of mine is, again, being unaware, even scared afraid of my body. My director wanted the military of Peck's background apparent in my body. To achieve this I first contacted the ROTC on campus. Unfortunately, 
all the military personnel on campus disperse over the summer for trainings at various bases. I went into auditions without having found anyone to help me physicalize the stance and stride of an ex-military man. After the first two weeks of rehearsals my director grew concerned that I quickly find someone to coach me for this. My demeanor and walk simply did not have the sternness he wanted in this character. As much as I tried to fake it, I simply did not have the experience to pull this off.

Shortly after this, 1 learned one of my Acting for Non-majors students, Christian Marinacci, was in the National Guard. He generously helped me give my physical performance more of a militaristic look and feel. He was able to teach me some of the psychological effects of military life along with the specifics of turning "about face." This physical act of turning my body 180 degrees smoothly was particularly difficult for me. It took constant practice and many stumbles to get this under control. One of the last things I did before entering the stage each night was to rehearse my "about face."

In addition to this attempt to transform my physical stance, I needed to transform my then long hair. I needed the hair cut of a man who has never fully let go of his military life. Finding a picture of a crew cut was easy enough, but I was worried about finding a stylist who would not make the cut look too modern since the play was set in the 1960 s and the military cuts of the $21^{\text {st }}$ century can be quite different than what I needed. Luckily, I did find a woman who was able to grasp what I was needed. The results were stunning. The haircut itself was done right but the effect it had on me in my portrayal was beyond what I had imagined. 
Seeing myself every morning with a severe hair cut so drastically different than any style I had worn before changed how I felt inside my own body. Professor Tompkins even noted how great a help the hair cut was in transforming my demeanor and interactions; as he said after a rehearsal, "Soft hair, soft character."

\section{Dialect Work for the Role}

Initially, research in this area centered around hunting for sound files of a South Carolina dialect and simply reading the script over (with emphasis on the "fishing" monologue) to find what character clues and speech rhythms I could glean. My initial explorations delved into the Speech Accent Archive, a website sponsored by George Mason University. Listening to these first samples it seemed that a South Carolina accent from the Charleston area was not much different than what I grew up hearing in rural southwest Ohio. From there I searched through National Public Radio's website looking for stories about South Carolina. I found several helpful audio examples and began working on recreating what I heard. Learning to use the International Phonetic Alphabet in Voice classes was invaluable in helping me to go beyond parroting what I heard and finding how my body makes the necessary vowel sounds.

Then, a wonderful bit of kismet occurred. Triza Cox, a second year graduate student from South Carolina, told me she grew up near Horry County, where Peck grew up. Triza was quite excited and eager to help me find sound recordings of authentic Horry County speakers. One You Tube video in particular was extremely helpful. It consisted of three or four different men who were 
speaking in natural settings: a court room or council meeting. This was a huge breakthrough for me. I had authentic, non-actors speaking the accent I needed to bring much more of Peck's full humanity onto the stage. Once I had the accent in my ear and, more importantly for me, in my mouth, so much of the character's charm and sense of being poured through. I was able to detach from myself as a man and actor and come a good bit closer to the essence of the character. Vocal patterns, 1 learned, are extremely important in finding and portraying a character honestly and completely. My director even commented how the accent gave so much more to my portrayal.

The problems outlined thus far fall into two categories: artistic problems and actor's problems. I define "artistic problems" as those challenges inherent in the role as written and in the role's portrayal. "Actor's problems," on the other hand, are issues and challenges that confront the actor's body and/or imagination in the process of embodying and fully creating a character. In order to solve these problems and overcome the obstacles in my process I implemented techniques I have developed in this graduate program.

Addressing the artistic issues, I started studying lines over the summer before the school year started, as I mentioned earlier. Peck's "fishing" monologue was a particular target for memorization. This effort revealed that it is much more difficult for me to memorize dialogue without another voice in the room than it is to commit the back and forth between two or more characters to memory. Still, this study paid off as I was able to rather quickly stop using the script during the second round of auditions. 
Additionally, once table readings started, I took character notes on Peck. Descriptions such as Li'l Bit's statement about the nighttime summer air making "a middle aged man with a mortgage feel like a country boy again" (Vogel, p. 9), and Li'l Bit's mother calling him "a small town hick who learned to mix drinks from Hugh Hefner" (p. 56) told me much about not only the condition of Peck's life but also something of what he was trying to recapture through his relationship with Li'l Bit. Moreover, I was committed to warming up vocally as well. I regularly set aside thirty to forty-five minutes before rehearsals to thoroughly warm up my voice and get focused for the creative work ahead of me. Rehearsals were a great exercise in communal contribution to the creative process, so I knew having my mind and heart present in the room was an absolute necessity.

Solving my actor's problems involved a constant vigilance against my bad habits such as relying on merely speaking resonantly and fully when I am disconnected from my character's intentions (which causes me to appear unaffected by the actors around me and detached from my own thoughts and feelings), downward vocal inflections, and not fully committing to the physical portrayal of a character. The skill of remaining constantly aware of my physicality while simultaneously remaining open and available for my fellow cast members and director, was noticeably sharpened for me by this rehearsal process.

Importantly, I was able to approach both sets of problems by putting my full trust in my director. I knew James Tompkins would not put up a production that did not meet his own exacting standards. He holds these standards in his classes as well as his plays so I knew that if I could reach the bar he set I could 
feel confident and well-grounded in what I presented on stage. His fine-tuned ear for vocal inflections as well as sharp eye for the sheer aesthetics of a play were invaluable in helping me to achieve the portrayal of Peck as a full and complex human being and, thus, to realize my main actor's goal. The skills and selfawareness I have developed through this process I know will serve me well throughout my artistic career.

Senior Military Advisor for the Army ROTC Department, Master Sergeant Martin W. Fawbush was very gracious in providing some help through e-mail. In particular, he stated that World War II veterans seemed to not be "very boastful around others about the things they did overseas during the war." This was certainly true of my own father who only talked about the humorous things that happened during his time in the service. Peck, for his part, not only resists talking about his military experience but is just as secretive about his birth family, especially his relationship with his mother.

While Peck's elusiveness is apparent in the play's text, MSG Fawbush's unsolicited comment on this particular characteristic helped to reinforce what I, nevertheless, needed to do as an actor, specifically justifying dramaturgically everything about a character's personality and actions. This includes the seemingly unjustifiable, i.e., Peck wanting to sleep with his niece, as well as more subtle facets of his personality such as wanting to keep certain information about his past a secret.

This elusiveness gave room for my imagination to take off and fill in the gaps that the playwright purposefully left in Peck's on-stage story. What I created 
was interesting and filled a small but potentially static moment towards the end of the restaurant scene where Li'l Bit continues asking Peck about his home and mother. Finally, a drunken Li'l Bit declares, "I bet your mother loves you, Uncle Peck," and the following stage directions state, "Peck freezes a bit" (p. 21). The reason for this familial tension is never revealed or even hinted at for the audience. If I created a bland history or even ignored that small but important moment, the audience would have been given one less opportunity to care for Peck or about his situation. I decided for myself that Peck is the victim of sexual abuse by his father and his mother knew of the abuse but, in Peck's eyes, did nothing to stop her husband. I could sense thoughts such as "Did she really love me?" and "Then why didn't she stop him?" start to form, but Peck's attention turns to the waiter and then to making as discreet an exit as possible with a drunken Li'l Bit hanging from his neck. I do not know if this very small moment had any impact on any audience member but I am confident that, given the tight blocking and continuous action of the production, even a small empty moment would be quite apparent. 


\section{CHAPTER IV}

\section{MAPPING THE TERRAIN:}

\section{APPLICATION OF PROCESS IN REHEARSAL}

Use what talents you possess: the woods would be very silent if no birds sang except those that sang best. The greatest mistake a man can make is to be afraid to make one. -Ralph Waldo Emerson

\section{Journaling}

A major rehearsal tool for me was keeping a journal. I recorded ideas, impressions, and discoveries from the first auditions to the last curtain call. These entries concerned almost exclusively the actual process itself, my thoughts, reactions, musings, and challenges with some minimal discussion of events outside of rehearsals such as classes, my home life, etc. Looking over these entries now I see, of course, an actor striving to find all he can about his character. But just as importantly, there are pages that show an artist finding the inner strength and focus to prepare for a show even when many of the day's events worked against his feelings of confidence.

In addition to this was, notably, my script. Beyond the obvious need to learn lines, I used my script to keep almost all of my rehearsal notes. By the end of the play's run my script had nearly as many of my own pencil markings and notes as the printer's ink. Everything from blocking to reminders of vocal inflections to goals for each scene and intentions behind individual lines are scattered throughout my copy of the script. This not only has made the script 
itself a document of the entire process but it would also keep the evolution of the character and the overall staging in my mind as I reviewed lines and scenes.

Close to the play's opening, though, I had to take notes in my journal. The script simply became too crowded.

\section{Character Notes}

The technique of keeping character notes from the first reading proved itself to be an important tool in developing a thoroughly realistic and sympathetic character for Peck. Even though I had read and reread the script several times over the preceding summer, hearing actors' voices give life to the descriptions of Peck made by the other characters particularly struck me in our first read-through of the play as a cast. Impressions such as Peck being good with kids, having physical scars from the war, and how the summer air makes him feel like a boy again were just a few of the initial building blocks for this character which I found in the first rehearsal. Recording these impressions helped me immensely in finding specific admirable and sympathetic aspects of Peck's personality. Further, descriptions such as "a drawl of molasses in the way he speaks" and "bedroom eyes" (p. 53) told me what physical work I needed to do in order to fully portray Peck's humanity and contradictions. While the aforementioned dialect work helped me to find the "molasses" in my own voice, I needed to make a concerted effort to find and display the personal and sexual confidence in myself that Peck always carries.

\section{Body Preparation / Warm-up}


A large part of my efforts in this regard were in simply staying aware of how I held my body as Peck and the demeanor I would present to the world. The techniques and details Christian Marinacci taught me became part of my physical warm up before every rehearsal. I worked regularly on executing a proper and smooth "about face" and the military walk of this character. I felt I was making strides when one of the theatre department's staff saw me working on my walk in the hallway and exclaimed "Hey, that's not your walk. Are you doing a character?" I took that to mean I had shaken off my way of walking through the world and found an aspect of Peck's body within my own.

\section{Vocal Preparation / Warm-up}

My vocal warm-up also remained very much the same, loosening my spine and jaw, warming up the entire range of my voice, and practicing articulators. By this point in my training and experience, I had gained enough understanding of my own vocal instrument that I could modify my warm-up as needed each night. If my upper resonators were feeling dead I would spent more time with them, getting enough air in my lungs to energize the sound and staying relaxed. I kept an open invitation to the rest of the cast to join me, and sometimes one or two would, but I was primarily concerned with keeping my own voice in order and ready for all the upcoming performances. Added to my vocal warm-up was a dialect recording I had made of the NPR sound files and the audio of the videos Triza Cox introduced to me. This recording was my touchstone, keeping me on track with that dialect's melody and, more importantly, the shape of 
various vowel sounds in my mouth until it became a habit to feel and hear the vowels' shapes.

\section{Breathing}

Breathing is an obvious aspect of any physical technique; we all need to breathe. But the rehearsal process for How I Learned to Drive drove home for me how breathing cannot function solely as the foundation of full vocal production. It can be an extremely effective springboard to the visceral experience of a character. Everything about the early training in the graduate voice class is rooted in relaxing, learning to find where tension exists in the body, and allowing - not forcing - the voice to come out. The foundation for this is a full, relaxed inhale. I was, not surprisingly, quite diligent to master this part of my training. My initial progress in these classes was swift and discernable-thanks, in no small part, to my undergraduate training in classical singing; much of the foundation of breathing is the same for classical singers as for stage actors.

This became the focal point of my body awareness at first, especially in performance. As I was able to habituate this sensation, I turned more of my focus on the physicality and dramatic motivations of my characters. By the time of my thesis role, the habit of always having a full open inhale was firmly engrained. In an early rehearsal of Peck and Li'l Bit's first scene Professor Tompkins asked me "How does he breathe during this?" I hadn't before thought of consciously producing a particular breathing pattern. The idea had been introduced to me more than once throughout my graduate training but I had never tried to implement it purposefully on stage. I assumed if I, as an actor, were truly 
invested in what I was saying and doing as my character then the breathing would come along. Nevertheless, old habits die hard. This one scene was the only time I purposefully manipulated my breathing pattern.

In the third week of rehearsals I noted in my journal "Use breathing to set up emotional states and spark emotional intent," and "Find breathing patterns for each scene and emotional landscape." Clearly, this idea was being talked about but it took time for the concept to settle into my performance. Then, a few rehearsals later, Tompkins pointed out that I was too in control of my breathing in the restaurant scene and, hence, I was coming across too controlled and uninvolved in the scene. I am not certain what it was about this moment that stood out for me but the concept finally sunk in.

Even so, I needed constant vigilance while performing to stay aware of my breathing. It remained very much a conscious effort throughout the run of the show. Since the close of How I Learned to Drive I have continued to try this technique in Repertory Company performances. While it can be effective for me in one particular scene, I do not employ it at every performance. That particular moment is brief and I need to be in another emotional state quickly; sometimes it is too difficult to fully recover for the next moment. 


\section{CHAPTER V}

\section{REACHING THE SUMMIT:}

\section{APPLYING MY PROCESS TO PERFORMANCE}

Theatre is a bright enigma. It produces moods, dreams, ideas, beauty, imagined characters. It is a form of incantation.

-Brooks Atkinson

Once rehearsals finished and the opening night curtain metaphorically rose, my process remained very much the same. Warm-ups before every performance-including between the two Sunday shows-were vital for me to remain relaxed, open, and focused. I continued to listen and measure myself against my dialect recording as part of the warm-up, though this diminished somewhat as the run progressed. Reviewing notes from the weeks of rehearsals helped to keep in mind the goals and individual intentions behind Peck's actions. This was especially true for one aspect common to Peck's scenes that I discovered and tried to keep in mind: Peck pushes towards his goal to what I saw as a specific "breaking point." Once he reaches this point, he quickly back peddles and tries to repair the damage he has done so that he can still attain his goal, whether it is to get Li'l Bit to enjoy her thirteen year old sexuality or to take driving seriously, or even to talk a little boy into a sexual encounter.

Perhaps the most salient and potent example of this is the hotel scene towards the end of the play. I could see that Peck drives through this scene up to 
the moment he opens the ring box and shows Li'l Bit he is quite serious about his marriage proposal. This, of course, is the one breaking point that cannot be repaired. Once I recognized this pattern, I noted in my journal where these breaking points occurred and reviewed them nearly every night. This helped me to find the various tactics Peck used not only in trying to secure his victory in each scene but in reassuring Li'l Bit or cousin BB that his intentions were honorable once he hit that scene's breaking point.

My journaling continued, of course. At first I continued the journal through the performances merely as a resource for writing this thesis. As I continued throughout the run to write out my thoughts and feeling about the trials and emotional turmoil of an MFA theatre program, I realized that, despite the personal struggles and hurt I had experienced, writing out my upset and outrage enabled me to better let go of any particular incident and bring much more of my whole self as an actor and a person onto the stage for my cast mates.

Apparently, the exorcizing of my emotional demons through journaling was a great help. As I looked back over my entry on the day after opening night I wrote that I felt relaxed in the role of Peck. This ease of being in the role, consequently, rippled through most of the performance. I noted in my journal how natural and spontaneous the photo shoot scene was and how much better the "fishing" monologue went compared to the previous night's final dress rehearsal. Conversely, I recorded how I felt I was pushing in the driving lesson scene. My note to myself was simply to reinforce my goal for the scene and to find additional tactics to achieve it. 
Journaling also helped me to buoy myself as I searched for confidence in what I was presenting on stage and as an artist as well. I reminded myself that I must be wary of taking compliments too much to heart and relying on those external validations to confirm my worth as an actor and artist. Whatever work I do on stage has to be to my personal artistic standards. I vehemently affirmed to myself that I am a good actor, an intelligent artist, and that my work does have meaning behind it. I knew I was exceptionally fortunate to be able to not only take on a quality role for my thesis but one I suggested and very much wanted to perform. I had no intentions of wasting this opportunity.

As my journaling continued, I was able to let go of moments that worked well a previous night by writing them down. My debilitating habit of stubbornly recreating what seemed to work in a performance or rehearsal was almost completely ironed out of me. This enabled me to enjoy moments on stage as they happened but not worry that my well of creativity would run dry after one spontaneous moment of inspiration.

I did try one new technique that I had never before employed. I put together a play list of artists as diverse as Joan Armatrading, Sade, Miles Davis, and the Red Hot Chili Peppers on an mp3 player. I listened to the songs most nights as I readied myself in the dressing room and let the ideas of love as unrequited and betrayed, or as simply beautiful and overpowering, flow into my subconscious. I cannot say definitively that this made a huge difference in any given performance or for the run overall, but it was a visceral doorway into the mindset and emotional turmoil that Peck had to revisit and re-experience every 
night. It is worth mentioning that I did make a journal note about the second night when I did not use the music. Despite having a sold out house, the audience was strangely quiet before the show started. There was no house music playing for this production and the silence was unnerving. I reminded myself to keep my energy up, to review my goals and breaking points, and that my cast mates were relying on me. It must have been effective; my entry the next night says that the show went well and we would build on that.

Having put in the weeks and weeks of work while remaining diligent to my weaknesses and old habits throughout the rehearsal process enabled me not to worry or even think much about the show during my classes once the run began. I do not recall having any nervousness the day of opening night. Using all of the tools I had acquired to that point-researching, dialect work, character notes, journaling, thorough warm-ups, and finding compelling goals and intentions-led me to be very relaxed and comfortable in Peck's shoes. With the "work" done, the "play" could begin, so to speak.

The actor's work on stage is, I have surmised, never really done. As artist Paul Gardener is quoted: "A painting is never finished-it just stops in interesting places. ${ }^{4}$ There is always more to discover and be surprised about, from the other actors and myself as well. At the end of the run I wanted at least another week of performances. As emotionally, physically, psychologically, and technically challenging as the role of Uncle Peck was for me, I knew there was so much more room for the role and the character to sink into my subconscious and my muscles.

\footnotetext{
${ }^{4}$ As quoted on the website musicthoughts.com (http://musicthoughts.com/t/659).
} 


\title{
CHAPTER VI
}

\author{
MORE ROADS TO TAKE: \\ USING THIS PROCESS IN THE FUTURE \\ We are happy...What do we do now, now that we are happy? \\ - Samuel Beckett (from Waiting for Godot)
}

\section{Fee script for Chautauqua program}

Using these tools I have already been able to apply my process-such as it is at this point-to projects beyond How I Learned to Drive, namely, a script I am developing for Chautauqua program (as I mentioned in Chapter 2) and the Acting class of my final semester. In the case of the former, I naïvely thought I could take a stentorian and sententious $19^{\text {th }}$ century autobiography and simply transcribe it into a dramatic piece. Eventually, I understood that this would not yield much theatrical treasure. I was able to rework the language and scenarios I had written into something much more dramatically viable and accessible.

Nevertheless, beyond the elementary task of editing a first draft, certain techniques of my process remained useful for me as I took my first foray into writing a performance piece outside of academia. The historical accuracy of the Chautauquan presentations is expected to be at a fairly high level. Hence, research was as vital for this project as any academic assignment I had in 
graduate school. As I read more about my subject, I found occasional descriptions that I could and did use just as I utilized character notes from a wellestablished script. I was quite taken aback to see the word "gregarious" used to describe the man who wrote in such a haughty and self-righteous style.

Additionally, a contemporary of Fee, Cassius Clay, recorded how untrained Fee's physical gesturers were despite his time at Lane Seminary. These historical sources showed me a clear path to finding an accessible and recognizable humanity in this character.

Additionally, dialect work in Voice class in the second semester of my second year had given me the foundation and tools I needed to document and hone in on that specific dialect. Among the various dialects on which we worked, one could be of our own choosing. I decided to work on a northern Kentucky dialect, specifically from Bracken County on the Ohio River, to prepare for the Chautauqua program audition that following summer. This preliminary work was, of course, quite helpful but dialect work remained difficult and trying. Even though I did not use the dialect in my audition, I was able to hone the accent and have it ready by the time I had to preview my work to the Humanities Council in early February.

In the script John Fee will be seen in various ages from about twenty-two up to fifty. Vocal warm-ups have been vital in opening up all the resonance in my voice but also for finding all the tones and colors I will need to portray an eager, idealistic young man through to an established, well-respected, but zealous family man on a mission. My physical warm-up for this piece is certainly not as 
intense as I described in Chapter 2. My main goal for the physical warm-up is to keep my body loose and responsive to my impulses and instincts and to keep me from making Fee too genteel. I have discovered that if I do even a simple stretching warm-up I feel much more comfortable in my body and on my feet. Having loosened up my physical self, I find I no longer think about my body in terms of what I can and cannot do but instead I am able to pay much more attention to my placement and positioning on stage while remaining open to and aware of my scene partner or, in this case, my audience.

Journaling, notably, has not been part of the process of developing this script. I have, however, been keeping extensive notes on the historical revelations that my research has brought up and the various impressions of John Fee I have gleaned from his contemporaries as well as from modern historians.

\section{Current Acting class}

While I was zeroing in on the final portion of my Chautauqua script, I had my final Acting class of my graduate career. In this class we were to conceive and develop an original solo performance piece of twelve to fifteen minute's length. Nothing was off the table for our ideas except that nothing could require copyright permission. Being so immersed in trying to meet the deadline of the Chautauqua preview date, I put no real effort into constructing another performance piece. As I watched my classmates bring exciting and interesting personal work to the class, my demon of self-doubt once again reared its ugly head. I lost confidence in my initial concept of enacting one of the many "Anansi the Spider" tales and did not believe that I, as an artist, could solve the problem 
in front of me. After completely changing my concept, I threw together a rough outline of what I thought could happen, but never got on my feet to work through it. Hence, I fell flat on my face at my first showing and spiraled into despondency and depression. Time for my second showing eventually grew near and I anxiously worked through and rejected various ideas until I came back to my original concept. Once I was moving around the rehearsal room, working through the story and discovering how to show the actions through the different animals in the story, I discovered so much more than merely sitting and thinking would ever have brought to light.

This simple technique of creating and writing on my feet has proven to be perhaps the single greatest tool I have developed. I cannot create visceral theatre work, neither in an original nor a well-established play, if I do not allow myself to start to move my body almost right away. I still struggle with the embarrassment of weak dramatic choices or narrating stage action rather than showing it. Nonetheless, allowing my body-not just my mind—-to stumble through where the story should go and thereby to find how best to tell it, even as I am actively composing, helped me to craft my original concept and to find the fun in performing as a spider, a python, a leopard or an $19^{\text {th }}$ century abolitionist minister. 


\section{CHAPTER VII}

\section{WHY I CONTINUE THE JOURNEY:}

\section{MY IDEAS ABOUT ACTING AND THEATRE NOW}

Be not just good; be good for something.

- Henry David Thoreau

My time at the University of Louisville has given me the opportunity to play and explore a wide variety of characters, well beyond what little I have shared in this thesis. I have found amoral ambition and grotesque sexiness as the Duke of Gloucester in Richard III, relished in the exuberance of a sixteen year old in love in As You Like It, and embodied passion for art and compassion for society as an arrogant genius with a severe speech impediment in Mephisto, to give just a few examples.

The training I have been under and the process I have developed has solidified for me the absolute necessity for me as an actor to use my entire body in rehearsal and on stage and all I truly have is my body and my imagination. One of the first tenets of acting introduced to me at the university is "All the actor has is the body and the voice." I realize, now, that this is not entirely accurate. My body, first and foremost, is my primary tool for reaching my audience and everything that goes into vocal sound production is a part of the physical body. If my body is relaxed and open to the actors around me my voice will follow suit. 
My voice will respond to whatever stimulus I receive, whether from an external source or, equally important, from my imagination. Working on scenes in Acting classes, constructing solo and group compositions in Movement, and, especially, preparing for the Chautauqua program has shown me how vital is an active and vivid imagination. Even with full costuming and an elaborate stage setting, I must be able to create the world in which I live through the course of a play for myself and in my own mind.

Still, imagination is not enough in and of itself. An actor's body must be relaxed and healthy so the voice can be open and responsive in order to communicate effectively and move an audience as well as the other actors. This openness and responsiveness in an actor's voice along with his very being while on stage make the stories enacted onstage believable, visceral and, hence, accessible for the audience. Theatre is a visceral art, much more than film and video. In theatre the audience breathes the same air as the actors who, if they have done their work conscientiously, become transformed into the characters the audience comes to love or hate-or both.

This begs a question: Why do we pay good money to sit for two hours and watch people pretend to go through a make believe story? We all value our own personal story and we long to share that story-even the more horrific aspectsin some way or another. Since this sharing can be and is such a frightening prospect, watching a character's story allows us to experience and, in an admittedly somewhat removed manner, to express our story vicariously through the actors who share the room and the air. 
I do not see this as an Aristotelian catharsis ${ }^{5}$ but, instead, as a validation of one's worth as a human being and a declaration that, as horrific as an experience may be, there is no use in remaining bound by shame or feelings of isolation. Similar to the healing that can come from talking to a therapist, seeing one's story told by a stranger with compassion and nobility can instill in any given audience member a measure of strength to face the present challenges of a damaged past. Even for those who do not see their own story on stage, witnessing and experiencing another's actions and the ensuing consequences on stage is a potent reminder of the strengths and weaknesses, the victories and failures that we all experience. In other words, we all experience a common humanity through stories we may not otherwise encounter.

This is why I continue to pursue theatre. This is why I came back to school twenty-five years after receiving my Bachelor's degree. I have found that I am more content, hopeful, and happy as I work in the theatre. This sense of wholeness within one's self and of having a place in the world is what I want to give to others through my art. I want my theatre to promote change, at the very least, in any given individual sitting in the audience. Television and film are much more apt to lull us into a passive acceptance of diversion. Not often does either truly make us contemplate our inner selves, our existence, our beliefs, our prejudices.

\footnotetext{
${ }^{5}$ In the book Poetics, the ancient Greek philosopher Aristotle codified what he saw as the consistent aspects of the plays presented at an annual competition. One of his ideas that has influenced Western dramatic art for centuries is that an on-stage drama allows the audience to purge themselves of emotion by watching the characters go through their own emotional turmoil as a result of their actions. Thus, having experienced the emotions while sitting in the theatre, the audience would not wallow in them and would become a more rational citizenry.
} 
Rinda Frye tells her students that the words theatre, therapy, and theology all share a common etymological root. This, for me, is the confluence of my life and art today. My spiritual beliefs fuel and inform everything I do onstage. Abdu'lBaha, son of the founder of the Baha'i Faith", declares "[l]n this wonderful new age, art is worship. The more thou strivest to perfect it, the closer wilt thou come to God," and "The drama is of the utmost importance. It has been a great educational power in the past; it will be so again" (The Importance of the Arts in Promoting the Faith: A Compilation, p. 10). For everyone, the future is a chance to change the world for the better. We are put on this earth for the betterment and edification of humanity through whatever capacities we are given. I fiercely portrayed Simon Legree not because I enjoyed acting out in such an obscene manner but to give an audience an opportunity to consider who they are by seeing what they are not or might be. I portray and embody the struggle and fear of being an isolated abolitionist in the midst of slave owners to show people that righteousness remains noble in the face of opposition while villainy subjugates and silences dissent. If I can spark even a moment of self-reflection or give a moment of encouragement to someone striving to improve the world for all people then I have begun to fulfill my purpose for living-beyond, of course, nurturing my own children.

I am not sure that theatre, in and of itself, will change the world but I am certain I can touch individuals through my theatre and individuals will, in turn, change the world. I hope to meet and work with artists who are in theatre for

\footnotetext{
${ }^{6}$ The Baha'i Faith was founded in 1863 in Iran by Mirza Huseyn-Ali, who took the name Baha'u'llah (meaning "the glory of God) and has since grown into a world-wide religion.
} 
more than being in a spotlight and telling an entertaining story. We thespians have been given great gifts not only in our talents but in our very desire to do theatre. We need to serve the world around us with those gifts. I intend to do so. 


\section{REFERENCES}

Aristotle (translated by S. H. Butcher). (1997). Poetics. Toronto, Canada: Dover Publications, Inc.

Carnicke, S. M. (2000). Stanislvski's System: Pathways for the actor. In A. Hodge, Twentieth Century Actor Training (pp. 11-36). New York, NY: Routledge.

Ewing-Roush, A. (2010, September 28). Aspects of Pedophilic Behavior. (K. O. Ewing-Roush, Interviewer)

Ewing-Roush, K. O. (n.d.). personal journal. unpublished.

Fawbush, M. W. (2010, July 28). Aspects of a Military Man's Psychology. (K. O. Ewing-Roush, Interviewer)

Justice Reform. (2008). Horry County, SC Public Corruption . . Fact or Fiction. Retrieved September 30, 2010, from YouTube:http://www.youtube.com/ watch? $v=\_8 P P 5 z X P O P M \&$ feature=channel

Meisner, S. and Longwell, D. (1987). Sanford Meisner on Acting. New York, NY: Random House.

National Public Radio. (2010, October 1). South Carolina sound files. Retrieved October 1, 2010, from National Public Radio: http://www.npr.org/ templates/search/index.php?searchinput=South+Carolina+sound+files

Schultz, P. D. (2005). Not Monsters: Analyzing the Stories of Child Molesters. Oxford, UK: Rowman \& Littlefield Publishers, Inc.

Stanislavski, C. (translated by E. Hapgood). (1961). Creating a Role. New York, NY: Routledge.

The Importance of the Arts in Promoting the Faith: A Compilation. (1999). Thornhill, Ontario, Canada: Baha'i Publications Canada.

Vogel, P. (1997). How I Learned to Drive. New York, NY: Dramatists Play Service, Inc.

Yale University. (2007). Faculty and Staff. Retrieved March 19, 2010, from Yale School of Drama: http://yaledrama.net/facebook/ 


\section{CURRICULUM VITAE}

\section{K. OBADIAH EWING-ROUSH}

4141 S. $5^{\text {th }}$ St., Louisville, KY 40215 | (615) 545-4431 | o.e.roush@insightbb.com

\section{EDUCATION}

University of Louisville, Louisville, $\mathrm{KY}$

M.F.A. in Theatre Arts

Thesis: "Lessons from the Journey: Developing and Applying an Actor's Process through Embodying "Uncle Peck" in

How I Learned to Drive"

Otterbein College (now University), Westerville, $\mathrm{OH}$

B.M.E in Music Education

1985

AWARDS

Warren Oats Award for outstanding graduate theatre students.

2011

\section{TEACHING EXPERIENCE}

Instructor, Acting for Non-majors, University of Louisville

Developed syllabus and overall course structure, including daily class presentations and bi-weekly written tests, and administered all grades.

Teaching Assistant to Drs. Russell Vandenbroucke and Amy Steiger in "Enjoyment of Theatre,"

University of Louisville

$2009-10$

Collaborated on curriculum and exam development, met with students upon request, and graded all written work and projects, including final exams/projects.

\section{RELATED EXPERIENCE}

Kentucky Humanities Council

Chautauqua Performer

Researched, wrote, and performs an original one-man

play as John G. Fee, Kentucky abolitionist and

co-founder of Berea College.

University of Louisville Department of Theatre Arts

Assistant director, How Orisanmi Chose his Head 
Assisting Professor Nefertiti Burton in directing, staging, and rehearsing for the university's Mainstage production.

University of Louisville Department of Theatre Arts Repertory Company Member

Actor with a four member troupe performing two different plays four days per week throughout the Jefferson County (KY) school system.

University of Louisville Delphi Center Graduate Assistant Teaching Academy

Attended a series of monthly trainings designed to enhance the learning experience for both instructor and student.

PUBLICATIONS AND PAPERS

"Emancipation for All: How One White Male Finds a Voice

Through Glenda Dickerson's Black Womanly Ensemble Theatre" Published in Black Masks magazine. Vol. 25, No. 1

"Emancipation for All: How One White Male Finds a Voice Through Glenda Dickerson's Black Womanly Ensemble Theatre" Paper presented to the International Colloquium of the National Black Theatre Festival, WinstonSalem, NC

\section{MEMBERSHIPS}

Southeast Theatre Conference (SETC) Golden Key National Honor Society The African American Theatre Program, University of Louisville 